\title{
Pengaruh Pembelajaran Tematik Integratif Terhadap Kemampuan Berpikir Kreatif Siswa
}

\author{
Atang Sutisna, Santi Rahmawati \\ Program Studi PGSD STKIP Muhammadiyah Kuningan \\ Jl. Syeh Maulana Akbar, Purwawinangun, Kec. Kuningan, Kabupaten Kuningan, Jawa Barat \\ E-mail: atangsutisna@upmk.ac.id
}

\section{Article Info}

Received Agustus 2020 Accepted September 2020 Published Oktober 2020

Keywords: Integrative learning, thinking.

thematic creative

\section{Abstract}

This study aims to determine the effect of integrative thematic learning on the creative thinking abilities of fourth grade students at MI PUI Cikaso. This type of research is quantitative with a design form using Quasi Experimental Disgn. The study population was all students in class IV MI PUI Cikaso totaling 48 students. The sample is class IV A as a control class with 24 students and class IV B as an experimental class with 24 students. This study uses 5 items pretest and posttest essay test items. Data collection techniques used were normality test, homogeneity test, and hypothesis testing. The results showed that integrative thematic learning with the help of traditional games had an effect on students' creative thinking abilities. This is evidenced by obtaining the results of the hypothesis Sig. (2-tailed) $=0.002<\mathrm{\alpha}=0.05$ then $\mathrm{H} 0$ is rejected and $\mathrm{H} 1$ is accepted, meaning that there is an effect of integrative thematic learning on students' creative thinking abilities.
\end{abstract}

\begin{abstract}
Abstrak : Penelitian ini bertujuan untuk mengetahui pengaruh pembelajaran tematik integratif terhadap kemampuan berpikir kreatif siswa kelas IV MI PUI Cikaso. Jenis penelitian yang digunakan adalah kuantitatif dengan bentuk desain menggunakan Quasi Eksperimental Disgn. Populasi penelitianya adalah seluruh siswa kelas IV MI PUI Cikaso berjumlah 48 siswa. Sampelnya adalah kelas IV A sebagi kelas kontrol dengan jumlah siswa 24 dan kelas IV B sebagai kelas eksperimen berjumlah 24 siswa. Penelitian ini menggunakan 5 butir soal tes essay pretest dan postest. Teknik pengumpulan data yang digunakan adalah uji normalitas, homogentias, dan uji hipotesis. Hasil penelitian menunjukkan bahwa pembelajaran tematik integratif dengan bantuan permainan tradisional berpengaruh terhadap kemampuan berpikir kreatif siswa. Hal tersebut dibuktikan dengan diperolehnya hasil hipotesis Sig. (2-tailed) $=0,002<\mathrm{a}=0,05$ maka $\mathrm{H}_{0}$ di tolak dan $\mathrm{H}_{1}$ di terima artinya terdapat pengaruh pembelajaran tematik integratif terhadap kemampuan berpikir kreatif siswa.
\end{abstract}

Kata kunci : Tematif integratif, berpikir kreatif. 


\section{PENDAHULUAN}

Pendidikan bertujuan untuk menghasilkan sumber daya manusia yang memiliki kompetensi utuh, yaitu kompetensi pengetahuan, keterampilan, dan sikap. Pembelajaran yang dilakukan di kelas tidak cukup hanya mengembangkan salah satu aspek namun harus memfasilitasis siswa untuk mengembangkan tiga aspek kompetensi (pengetahuan, keterampilan, dan sikap) secara seimbang.

Pembelajaran tematik integratif atau kurikulum $\mathrm{k} 13$ yang saat ini diterapkan pada sekolah dasar prose pembelajarannya dilaksanakan secara holistik dan integratif serta berfokus pada alam, sosial dan budaya. Sementara itu menurut Trianto (2010), pembelajaran tematik dimaknai sebagai pembelajaran yang dirancang berdasarkan tema-tema tertentu. Dalam pembahasannya tema ini ditinjau dari berbagai mata pelajaran. Senada dengan pendapat tersebut Resmitha Nidya Viantari (2015) menegaskan bahwa pembelajaran tematik integratif yaitu pembelajaran yang menggunakan tema dari berbagai mata pelajaran yang dijadikan satu dalam satu kali tatap muka.

Pembelajaran tematik integratif merupakan pendekatan pembelajaran yang mengintegrasikan berbagai kompetensi dari berbagai mata pelajaran ke dalam berbagai tema. Integrasi tersebut dilakukan agar siswa memiliki pengetahuan yang kompleks tidak terkotak-kotak berdasarkan mata pelajaran, ada tiga hal yang diintegrasikan dalam pembelajaran tematik integratif yaitu integrasi sikap, keterampilan, dan pengetahuan Kemendikbud (2013).

Majid (2014) mengungkapkan bahwa pembelajaran temtik integratif memiliki tema yang aktual, dekat dengan dunia siswa dan ada dalam kehidupan sehari-hari. Tema ini menjadi alat pemersatu materi yang beragam dari beberapa mata pelajaran.

Pada pembelajaran tematik integratif siswa dilatih untuk memiliki kemampuan soft skills yang baik seperti jiwa kepemimpinan, kemampuan bekerjasama, kemampuan komunikasi, kemampuan berkolaborasi, dan lainlain. Selain itu pada proses pembelajarannya siswa dilatih untuk mengembangkan kemampuan berpikir tingkat tinggi (higher order thinking).

Menurut Ernawati (2017), berpikir tingkat tinggi atau Higher Order Thinking Skills (HOTS) merupakan cara berpikir yang tidak lagi hanya 
menghafal secara verbalistik saja namun juga memaknai hakikat dari yang terkandung diantaranya, untuk mampu memaknai makna dibutuhkan cara berpikir yang integralistik dengan analisis, sintesis, mengasosiasi hingga menarik kesimpulan menuju penciptaan ide-ide kreatif dan produktif. Kemampuan berpikir tersebut hendaknya mulai dikembangkan sejak usia sekolah dasar. Sementara itu menurut Sthepen krulik dan Jesse A. Rudnick (1995) proses berpikir dimulai dari basic, critcal dan creative.

Pada penelitian ini kemampuan berpikir yang diteliti yaitu fokus pada kemampuan berpikir kreatif siswa. Kemampuan berpikir kreatif yang diukur mencakup (1) kemampuan menghasilkan banyak ide dalam menjawab pertanyaan (fluency/ kelancaran), (2) kemampuan mengemukakan berbagai cara untuk menjawab pertanyaan (flexibility/ fleksibilitas), (3) kemampuan menciptakan ide orisinil untuk menjawab pertanyaan (originality/ keaslian), dan (4) kemampuan menuangkan ide lebih terperinci kedalam situasi baru (elaboration/ elaborasi) Munandar (Moma, 2015).

Kemampuan berpikir kreatif berada pada level tertinggi dalam proses kognitif (Kawuryan, dkk, 2018), proses berpikir kreatif ini menuntut adanya berbagai konsep pemikiran. Berpikir kreatif merupakan cara berpikir yang menghasilkan sesuatu hal baru dalam konsep, pengertian, penemuan, dan karya seni (Dennis, 2009).

Menurut Maxwell (2003) berpikir kreatif adalah gabungan dari ide-ide lain yang ditemukan pada waktu berpikir. Proses berpikir kreatif merupaka proses yang panjang dalam memperoleh gagasan baru. Gagasan baru tersebut dikaji terlebih dahulu sebelum muncul suatu ide yang benar-benar baru kemudian baru memunculkannya.

Kemampuan berpikir kreatif merupakan faktor penting yang dapat mempengaruhi proses pembelajaran. Artinya, di satu sisi guru perlu memiliki pengetahuan yang cukup tentang kreativitas sehingga di sisi lain dapat mengembangkan kreativitas siswa dengan cara yang tepat (Trnova \& TRNA, 2014). Strategi pembelajaran yang kreatif dengan menggunakan berbagai teknik atau permainan yang mampu mengembangkan kemampuan berpikir kreatif siswa. Subali dan Mariyam (2013) mengemukakan bahwa pengembangan kreativitas harus dibelajarkan seawal mungkin kepada siswa. 
Mengingat betapa pentingnya kemampuan berpikir kreatif untuk mengembangkan kualiatas hidup seperti yang dijelaskan di atas maka perlu adanya suatu latihan atau pengembangan sejak dini. Sekolah dasar merupakan salah satu pendidikan formal yang mengajarkan proses kognitif maka dari itu perlu adanya suatu pembiasaan dalam hal mengembangkan kemampuan berpikir kreatif khususnya pada usia anak SD.

Diantara cara untuk mengembangkan kemampuan kreatif siswa yaitu memberikan kesempatan kepada siswa untuk menemukan sendiri, merasakan dan melakukan senidiri proses pembeajarannya sehingga melahirkan pengelaman bermakna. Hal tersebut senada dengan ciri pembelajaran tematik integratif yaitu: berpusat pada siswa; memberikan pengalaman langsung; pemisah mata pelajaran tidak begitu jelas; menyajikan konsep dari berbagai mata pelajaran; bersifat fleksibel; menggunakan prinsip belajar sambil bermain dan menyenangkan (Abdul Majid, 2014),

Menurut Ghosh (2015) aktivitas yang dilakukan oleh siswa SD selain belajar adalah bermain. Diantara jenis dan bentuk permainan yang memberikan nilai posotifi yaitu permainan tradisional karena permainan tradisional berasal dari lingkungan siswa. Lingkungan anak-anak sendiri telah banyak menyediakan berbagai jenis permainan tradisional yang dapat dimainkan sesuai tingkat perkembangan usianya.

Anak akan lebih terlihat aktif pada saat melakukan aktivitas bermain. Kehidupan anak identik dengan dunia bermain, sehingga secara tidak langsung permainan anak dapat digunakan sebagai penentu jalan hidupnya serta pembentuk kepribadiannya (Purwaningsih, 2006). Hal tersebut menunjukkan bermain tidak bisa dipisahkan dengan dunia anak. Hal tersebut senada dengan penelitian yang dilakukan oleh Romlah, dkk (2018) hasilnya adalah desain prototipe perangkat pembelajaran IPA menggunakan permainan tradisional sudah valid, praktis, dan efektif untuk melatihkan keterampilan berpikir kreatif siswa. Demikian pula dengan penelitian yang dilakukan oleh Dheny Wawan Febrian, dkk (2013) yaitu menunjukkan bahwa kualitas pembelajaran dengan menggunakan model pembelajaran TGT dengan pendekatan PMRI berbasis konservasi budaya dengan bantuan permainan tradisional dapat dikategorikan dalam kategori baik. 
Rahmawati (2010) menegaskan bahwa usia anak-anak merupakan usia yang sangat subur untuk mengembangkan kreativitas. Masa ini banyak memberikan waktu untuk melakukan kegiatan kreativitas melalui bermain. Bermain memberi kesempatan pada anak untuk mewujudkan ide-ide baru, menemukan sesuatu yang baru guna membentuk cita-cita yang unik dan kreatif.

Purwaningsih (Permainan tradisional anak, 2006) berpendapat bahwa permainan tradisional adalah segala bentuk permainan yang sudah ada sejak zaman dahulu dan diwariskan secara turun menurun dari generasi ke generasi. Permainan tradisional merupakan salah satu aset budaya bangsa yang harus tetap dilestarikan.

Permainan tradisional mempunyai manfaat yang banyak dalam membantu mengoptimalkan perkembangan anak, baik dari aspek kognitif, bahasa, fisik motorik, sosial emosional, kreatifitas, maupun nilai-nilai agama dan moral anak. Sementara itu, kemajuan teknologi membuat permainan tradisional tersingkir dengan permainan elektronik dan permainan komputer. Hal itu dapat disiasati dengan penyertaan pembelajaran yang berbasis pada penanaman karakter cinta kebudayaan daerah. Salah satunya yaitu dengan menggunakan permainan tradisional (Rahmawati, 2010).

Penggunaan permainan tradisional diharapkan akan tercipta sebuah pembelajaran yang menyenangkan, juga di dalam prosesnya akan menanamkan karakter peduli terhadap pelestarian kebudayaan daerah serta dapat mencapai tujuan dari pembelajaran itu sendiri. Sehingga dapat dikatakan bahwa dengan penerapan permainan tradisional dalam pembelajaran akan tercipta sebuah kegiatan pembelajaran yang efektif yang merupakan wujud pendidikan konversi budaya dan tentunya kegiatan tersebut diharapkan mampu mencapai tujuan yaitu meningkatkan kemampuan berpikir kreatif siswa.

Menurut Seto Mulyadi (Rahmawati, 2010), kreativitas ini mengalami proses penghilangan setelah seseorang mengikuti pendidikan di Sekolah Dasar. Ketika berada di bangku sekolah, seorang anak dilatih untuk memilih satu jawaban yang benar atau suatu persoalan dalam ujian. Hal ini menjadikan potensi berpikir kreatif tidak berkembang optimal. Proses penghilangan itu terus berlangsung hingga jenjang pendidikan mereka ada di lembaga pendidikan tinggi. 
Melihat fenomena proses pembelajaran saat ini diketahui bahwa saat pembelajaran berlangsung siswa kurang aktif, semangat belajar siswa yang rendah, motivasi belajar siswa yang masih rendah, dan respon atau jawaban dari pertanyaan-pertanyaan yang diberikan oleh guru pada siswa masih tergolong standar dan belum mencapai kategori-kategori pada kemampuan berpikir kreatif. Selain itu, penerapan permainan tradisional dalam proses pembelajaran pun masih jarang dilakukan oleh guru. Sehingga hal ini berdampak pada rendahnya kemampuan berpikir kreatif siswa.

Tujuan Penelitian ini untuk mengetahui kemampuan berpikir kreatif siswa kelas IV MI PUI Cikaso sebelum dan setelah melakukan pemelajaran dengan pembelajaran tematik integratif dengan bantuan penerapan permainan tradisional, dan untuk mengetahui apakah terdapat pengaruh permainan tradisional terhadap kemampuan berpikir kreatif siswa kelas IV MI PUI Cikaso. Oleh karena itu penelitian ini fokus pada pengaruh pembelajaran tematik integratif menggunakan permainan tradisional terhadap kemampuan berpikir kreatif siswa.

\section{METODE}

Metode penelitian yang digunakan dalam penelitian ini adalah metode kuasi eksperimen (Quasi Experimental Design). Desain ini mempunyai kelompok kontrol, tetapi tidak dapat berfungsi sepenuhnya untuk mengontrol variabel-variabel luar yang mempengaruhi pelaksanaan eksperimen. Desain penelitian yang digunakan adalah Nonequivalent Control Group Disgn, melibatkan dua kelompok; kelas eksperimen dan kelas kontrol. Pada desain ini kelas kontrol maupun kelas eksperimen tidak dipilih secara random. Pada pelaksanaan pembelajaran kelas eksperimen akan menerapkan permainan tradisional, sedangkan untuk kelas kontrol dalam kegiatan pembelajarannya menggunakan pembelajaran konvensional.

Desain penelitian kuasi eksperimen Nonequivalent Control Group Disgn ini dapat dilihat pada gambar berikut: 


\begin{tabular}{|llll|}
\hline $\mathrm{E}:$ & $\mathrm{O}_{1}$ & $\mathrm{X}_{1}$ & $\mathrm{O}_{2}$ \\
$\mathrm{~K}:$ & $\mathrm{O}_{3}$ & $\mathrm{X}_{2}$ & $\mathrm{O}_{4}$ \\
\hline
\end{tabular}

Gambar. 1

Desain penelitian

Keterangan:

E : Kelompok Eksperimen

$\mathrm{K} \quad$ : Kelompok Kontrol

$\mathrm{O}_{1}=\mathrm{O}_{3} \quad$ : Pretest

$\mathrm{O}_{2}=\mathrm{O}_{4} \quad$ : Posttest

$\mathrm{X}_{1} \quad$ : Diberikan perlakuan

$\mathrm{X}_{2} \quad$ :Tidak diberikan perlakuan

(Sugiyono, 2017)

Populasi dalam penelitian ini adalah seluruh siswa kelas IV MI PUI Cikaso yang berjumlah 48 siswa. Penelitian ini menggunakan teknik Random Sampling yaitu siswa kelas IV A sebagai kelas kontrol dengan jumlah 24 siswa dan kelas IV B sebagai kelas eksperimen yang berjumlah 24 siswa.

Instrumen yang digunakan untuk mengumpulkan data pada penelitian ini adalah tes. Tipe tes yang digunakan dalam penelitian ini adalah tipe uraian tertulis yang berjumlah 5 butir soal dengan tujuan kemampuan berpikir kreatif siswa dapat terlihat jelas dari cara menjawab soal-soal, juga dapat menggambarkan seberapa jauh proses berpikir dan kemampuan siswa dalam berpikir kreatif pada proses pembelajaran. Tes ini terdiri atas pretest dan posttest.

Pretest dilaksanakan untuk memperoleh data kemampuan awal kemampuan berpikir kreatif siswa, sedangkan Posttest dilakukan untuk memperoleh data kemampuan akhir kemampuan berpikir kreatif siswa. Sebelum digunakan dalam penelitian, soal tes ini diuji kelayakannya dengan uji validitas tes soal, reliabilitas, daya beda soal, serta tingkat kesukaran soal.

Pada kegiatan awal diberikan soal pretest soal essay untuk mengetahui kemampuan awal siswa. Setelah itu diberikan perlakuan pembelajaran tematik integratif dengan bantuan permainan tradisional pada tema 8 "Daerah Tempat Tinggalku" Subtema 3. Setelah rangkaian pembelajaran dilakukan maka pada hari terakhir siswa diberikan soal posttest berupa essay untuk mengetahui 
kemampaun berpikir kreatif siswa setelah mengikuti pembelajaran tematik integratif dengan bantuan penerapan permainan tradisional.

Pembelajaran tematik integratif dalam penelitian ini dibantu dengan penerapan permainan tradisional yang berjumlah 6 permainan diantaranya yaitu permainan Boy-boyan, Ketapel, Polisi-polisian, Pletokan, Kotak pos, dan Lempung. Pembelajaran dilakukan didalam dan diluar kelas. Tempat duduk ditata secara berkelompok agar memudahkan siswa dalam untuk bergerak dengan leluasa. Alat dan bahan yang digunakan dalam penerapan permainan tradisional ini cukup sederhana, dan dapat disediakan oleh guru atau dibuat oleh siswa.

Analisis data dapat dilakukan jika data sudah dilakukan uji analisis. Uji prasyarat analisis data meliputi uji normalitas dan uji homogenitas. Setelah kedua sampel diberikan perlakuan yang berbeda, maka data yang diperoleh dapat dianalisis untuk mengetahui peningkatan kemampuan berpikir kreatif di kelas kontrol dan kelas eksperimen. Data hasil tes akhir yang diperoleh digunakan sebagai dasar dalam menguji hipotesis. Uji hipotesis yang digunakan dalam penelitian ini adalah uji-t.

\section{HASIL DAN PEMBAHASAN}

Tes kemampuan berpikir kreatif disusun dengan bentuk uraian berdasarkan kriteria berpikir kreatif dan materi ajar yang dipelajari siswa. Untuk memperoleh data kemampuan berpikir kreatif, dilakukan penskoran terhadap jawaban siswa untuk setiap butir soal. Adapun kriteria penskoran tes kemampuan berpikir kreatif yang digunakan dalam penelitian ini adalah mengacu pada skor rubrik menurut Munandar (Moma, 2015).

Tabel. 1

Pedoman Penskoran Tes Kemampuan berpikir Kreatif

\begin{tabular}{|c|c|c|c|}
\hline No. & $\begin{array}{c}\text { Kategori } \\
\text { Kemampuan } \\
\text { Berpikir Kreatif }\end{array}$ & Keterangan & Skor \\
\hline \multirow{3}{*}{1} & \multirow{3}{*}{$\begin{array}{l}\text { Berpikir lancar } \\
\quad \text { (Fluency) }\end{array}$} & $\begin{array}{l}\text { Mampu memberikan banyak jawaban dalam menjawab } \\
\text { suatu pertanyaan. }\end{array}$ & 3 \\
\hline & & $\begin{array}{l}\text { Mampu memberikan jawaban yang cukup dalam } \\
\text { menjawab suatu pertanyaan. }\end{array}$ & 2 \\
\hline & & $\begin{array}{l}\text { Mampu memberikan sedikit jawaban dalam menjawab } \\
\text { suatu pertanyaan. }\end{array}$ & 1 \\
\hline
\end{tabular}


Mampu menghasilkanpenyelesaian masalah atau jawaban suatu pertanyaan dengan tepat.

Mampu menghasilkanpenyelesaian masalah atau jawaban suatu pertanyaan kurang tepat.

Mampu menghasilkan jawaban yang lain dari yang sudah biasa dalam menjawab suatu pertanyaan dengan tepat.

Mampu menghasilkan jawaban yang sudah biasa dalam menjawab dan sesuai dengan pertanyaan.

Mampu menghasilkan jawaban yang sudah biasa dalam menjawab dan sesuai dengan pertanyaan.

Mampu menghasilkan jawaban dan mengembangkan suatu jawaban dengan tepat.

Berpikir terperinci (Elaboration)

Mampu menghasilkan jawaban dan mengembangkan jawaban cukup tepat.

Mampu menghasilkan jawaban namun tidak mampu mengembangkan jawaban.

Berdasarkan hasil pretest dan posttest dapat diketahui bahwa terdapat nilai tertinggi, nilai terendah, dan nilai rata-rata hasil penelitian pretest dan posttest. Deskripsi nilai pretest dan posttest sisiwa dapat dilihat pada tabel berikut:

Tabel. 1

Nilai Pretest dan Posttest

\begin{tabular}{ccccc}
\hline \multirow{2}{*}{ Nilai } & \multicolumn{2}{c}{ Eksperimen } & \multicolumn{2}{c}{ Kontrol } \\
& Pretest & Posttest & Pretest & Posttest \\
\hline Terendah & 20 & 40 & 13 & 20 \\
Tertinggi & 60 & 93 & 53 & 87 \\
Rata-rata & 40.75 & 63.92 & 32.25 & 47 \\
\hline
\end{tabular}

Berdasarkan tabel 1 diatas menunjukan perbandingan perolehan nilai posttest kemampuan siswa dalam memahami materi di kelas kontrol yang tetap menggunakan pembelajaran konvensional dan kelas eksperimen setelah menerapkan permainan tradisional. Rata-rata nilai kelas kontrol untuk nilai pretest sebesar 32,25 sedangkan rata-rata posttest sebesar 47. Untuk kelas eksperimen rata-rata nilai pretest sebesar 40,75 sedangkan untuk rata-rata nilai posttest sebesar 63,92 .

Berdasarkandata pada tabel 1 dapat disajikan perbandingan dalam bentuk diagram sebagai berikut. 


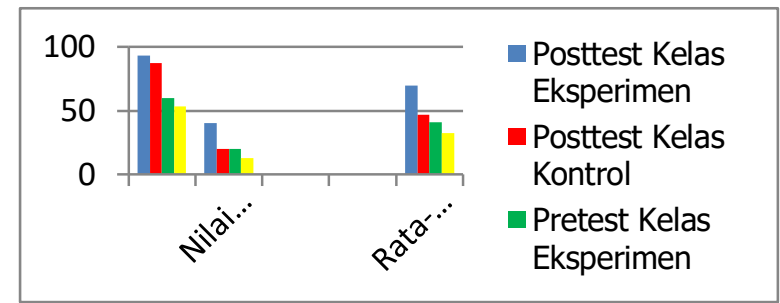

Gambar. 2

Diagram Nilai Pretest dan Posttest

\section{Uji Normalitas}

Uji normalitas data kedua sampel dengan menggunakan uji Chi-kuadrat menggunakan SPSS 21. Hasilnya sebagai berikut:

Tabel. 2

\section{Hasil Uji Normalitas}

Tests of Normality

\begin{tabular}{|r|l|r|r|r|r|r|r|}
\hline \multicolumn{2}{|l|}{} & \multirow{2}{*}{ JENIS_TES } & \multicolumn{3}{|c|}{ Kolmogorov-Smirnov ${ }^{\mathrm{a}}$} & \multicolumn{3}{|c|}{ Shapiro-Wilk } \\
\cline { 3 - 9 } & & \multicolumn{1}{|c|}{ Statistic } & \multicolumn{1}{c|}{$\mathrm{df}$} & \multicolumn{1}{c|}{ Sig. } & \multicolumn{1}{c|}{ Statistic } & \multicolumn{1}{c|}{$\mathrm{df}$} & \multicolumn{1}{c|}{ Sig. } \\
\hline \multirow{2}{*}{ NILAI_SISWA } & PRETEST KONTROL & .174 & 24 & .058 & .945 & 24 & .208 \\
& PRETST EKSPERIMEN & .148 & 24 & .188 & .919 & 24 & .056 \\
& POSTTEST KONTROL & .138 & 24 & $.200^{\circ}$ & .942 & 24 & .178 \\
& POSTTEST EKSPPERIMEN & .143 & 24 & $.200^{\circ}$ & .931 & 24 & .100 \\
\hline
\end{tabular}

*. This is a lower bound of the true significance.

a. Lilliefors Significance Correction

Hasil pengujian normalitas data pretest kelas kontrol melalui uji Shapiro-Wilk yaitu sig. $=0,208>a=0,05$. Maka data pretest kelas kontrol berdistribusi normal. Sedangkan data pretest kelas eksperimen yaitu Sig.= $0,056>\alpha=0,05$. Maka data pretest kelas eksperimen juga berdistribusi normal.

Hasil pengujian normalitas data posttest kelas kontrol melalui uji Shapiro-Wilk yaitu Sig. $=0,178>a=0,05$. Maka data posttest kelas kontrol berdistribusi normal. Sedangkan data pretest kelas eksperimen yaitu Sig.= $0,100>a=0,05$. Maka data posttest kelas eksperimen juga berdistribusi normal.

\section{Uji Homogenitas}

Setelah asumsi normalitas dipenuhi, maka asumsi selanjutnya yang harus dipenuhi adalah homogenitas varians. Berikut disajikan hasil uji homogenitas varians data pretest kelas kontrol dan eksperimen menggunakan SPSS 21 yaitu uji Homogenitas of varians (Levene Statistic). 
Tabel. 3

Hasil Uji Homogenitas

\begin{tabular}{cccc}
\hline Levene Statistic & df1 & df2 & Sig. \\
\hline 2.039 & 1 & 46 & .160 \\
\hline
\end{tabular}

Berdasarkan data di atas diperoleh $\operatorname{Sig}=0,160>a=0,05$ artinya kedua sampel memiliki varians yang homogen. Dengan demikian asumsi homogenitas varians terpenuhi.

Selanjutnya disajikan hasil uji homogenitas varians data Posttest kelas kontrol dan eksperimen menggunakan SPSS 21 yaitu uji Homogenitas Of Varians (Levene Statistic).

Tabel. 4

Hasil Uji Homogenitas

\begin{tabular}{cccc}
\hline Levene Statistic & df1 & df2 & Sig. \\
\hline .812 & 1 & 46 & .372 \\
\hline
\end{tabular}

\section{Uji Hipotesis}

Hipotesis yang diujikan dalam penelitian ini yaitu sebagai berikut:

$\mathrm{H}_{0}=$ Tidak terdapat pengaruh penerapan permainan tradisonal terhadap kemampuan berpikir kreatif siswa kelas IV MI PUI Cikaso.

$\mathrm{H}_{1}=\quad$ Terdapat pengaruh permainan tradisonal terhadap kemampuan berpikir kreatif siswa kelas IV MI PUI Cikaso.

Hasil perhitungan Independent Samples Test yang telah dilakukan dapat disajikan pada tabel berikut:

Tabel. 5

Uji Hipotesis

\begin{tabular}{|c|c|c|c|c|c|c|c|}
\hline \multirow{4}{*}{$\begin{array}{l}\text { Nilai_ } \\
\text { Postest }\end{array}$} & \multicolumn{5}{|c|}{ t-test for Equality of Means } & \multicolumn{2}{|c|}{$\begin{array}{l}95 \% \text { Confidence Interval of } \\
\text { the Difference }\end{array}$} \\
\hline & $\mathrm{T}$ & $\mathrm{Df}$ & Sig. (2-tailed) & $\begin{array}{c}\text { Mean } \\
\text { Difference }\end{array}$ & $\begin{array}{l}\text { Std. Error } \\
\text { Difference }\end{array}$ & Lower & Upper \\
\hline & -3.238 & 46 & .002 & -16.91667 & 5.22463 & -27.43331 & -6.40002 \\
\hline & -3.238 & 44.344 & .002 & -16.91667 & 5.22463 & -27.44392 & -6.38941 \\
\hline
\end{tabular}

Berdasarkan data di atas diperoleh Sig. (2-tailed) $=0,002<\alpha=0,05$ maka $\mathrm{H}_{1}$ diterima artinya terdapat pengaruh permainan tradisional terhadap kemampuan berpikir kreatif siswa. 
Penelitian ini merupakan penelitian eksperimen yaitu mengujicobakan penggunaan permainan tradisional pada pembelajaran tematik integratif untuk diketahui apakah terdapat pengaruh atau tidak ditandai dengan terdapat perbedaan rata-rata nilai pada kelas kontrol dan kelas eksperimen. Hal tersebut sesuai dengan hasil dan pengolahan pretest siswa pada kelas eksperimen nilai terendah dari hasil pretest adalah 20, nilai tertingginya adalah 60 dengan rata-rata 40.75 begitupun dengan kelas kontrol nilai terendah 13, nilai tertinggi 53 dengan rata-rata 32.25. Hal ini membuktikan bahwa kemampuan berpikir kreatif siswa masih rendah.

Selanjutnya hasil analisis dan pengolahan posttest sesudah menggunakan penerapan permainan tradisional untuk kelas eksperimen dan pembelajaran konvensional pada kelas kontrol pada kelas eksperimen memperoleh nilai terendah sebesar 40 nilai teringgi sebesar 93 dengan memperoleh rata-rata 63.92 , hal ini membuktikan bahwa penerapan permainan tradisional mampu meningkatkan kemampuan berpikir kreatif siswa.

Untuk data uji t taraf signifikan 0,05 dengan rata-rata nilai akhir kelas eksperimen sebesar 63,92 dan nilai akhir kelas kontrol dengan rata-rata 42. Maka hipotesis $\mathrm{H}_{0}$ yaitu tidak terdapat pengaruh penerapan permainan tradisional terhadap kemampuan berpikir kreatif siswa ditolak dan $\mathrm{H}_{1}$ diterima yaitu terdapat pengaruh permainan tradisional terhadap kemampuan berpikir kreatif siswa. Hal ini menunjukan bahwa terdapat perbedaan nyata antara kedua kelas. Dengan kata lain bahwa pembelajaran dengan menggunakan penerapan permainan tradisional berpengaruh terhadap kemampuan berpikir kreatif siswa.

Hasil penelitian tersebut didukung oleh penelitian sebelumnya yang dilakukan oleh Romlah, Muhammad Nur, dan Wahono Widodo yang berjudul desain prototipe perangkat pembelajaran ipa menggunakan permainan tradisional untuk melatih keterampilan berpikir kreatif siswa SD yang mempunyai kesamaan peningkatan kemampuan berpikir kreatif siswa. Berdasar analisis data, peningkatan hasil rata-rata tes berpikir kreatif dari komponen kelancaran (fluency), keluwesan (flexibility), dan keaslian (originality) ditunjukkan oleh nilai $\mathrm{N}$-Gain berada di persamaan $0.30 \leq(<\mathrm{g}>) \leq$ 0.70 , yakni sebesar 0.52 berkategori sedang. 
Pada kesempatan yang berebeda Ghosh (2015) menjelaskan aktivitas yang dilakukan oleh siswa SD selain belajar adalah bermain. Diantara jenis dan bentuk permainan yang memberikan nilai posotifi yaitu permainan tradisional karena permainan tradisional berasal dari lingkungan siswa. Lingkungan anakanak sendiri telah banyak menyediakan berbagai jenis permainan tradisional yang dapat dimainkan sesuai tingkat perkembangan usianya. Usia anak-anak merupakan usia yang sangat subur untuk mengembangkan kreativitas. Masa ini banyak memberikan waktu untuk melakukan kegiatan kreativitas melalui bermain (Rahmawati, 2010). Bermain memberi kesempatan pada anak untuk mewujudkan ide-ide baru, menemukan sesuatu yang baru guna membentuk cita-cita yang unik dan kreatif.

Selain itu, permainan tradisional akan menjadi pengalaman yang bersifat alami bagi siswa dan memberikan pengalaman bermakna dimana pengalaman tersebut dapat dijadikan sebagai pengetahuan yang kaya serta dapat mendukung pengembangan kemampuan berpikir mereka. Oleh karena itu bahwa pembelajaran menggunakan penerapan permainan tradisional memiliki pengaruh positif terhadap kemampuan berpikir kreatif siswa.

Tujuan dari hasil penelitian ini diharapkan dapat dijadikan rujukan atau bahan kajian dalam memilih dan menggunakan media atau alat peraga dalam proses pembelajaran. Demikian untuk peneliti selanjutnya serta guru agar dapat memperbaiki dan mengembangkan kekurangan-kekurangan yang terjadi pada proses penelitian atau pada teknis penggunaan permainan tradisional.

\section{KESIMPULAN}

Berdasarkan hasil dan pembahasan mengenai pengaruh penerapan pembelajaran tematik integratif terhadap kemampuan berpikir kreatif siswa kelas IV MI PUI Cikaso. Maka peneliti menarik kesimpulan sebagai berikut: (1) Kemampuan berpikir kreatif siswa pada kondisi awal masih rendah, hal tersebut ditunjukkan oleh hasil pretest kelas eksperimen memperoleh nilai rata-rata sebesar 40,75. Demikian pada kelas kontrol diperoleh nilai rata-rata sebesar 32,25; (2) Terdapat pengaruh pembelajaran tematik integratif dengan bantuan permainan tradisional terhadap kemampuan berpikir kreatif siswa dibuktikan dengan hail uji t yaitu memperoleh nilai signifikansi 0,002 0,05 dengan rata-rata nilai kelas eksperimen 63,92 dan kelas kontrol 47. Maka $\mathrm{H}_{1}$ di 
terima karena terdapat pengaruh pembelajaran tematik integratif terhadap kemampuan berpikir kreatif siswa kelas IV di MI PUI Cikaso.

\section{DAFTAR PUSTAKA}

Dennis, F. (2009). Berpikir kreatif. Jakarta: Esensi Erlangga Group.

Ghosh, P. (2015, May-June). Traditional Sports and Games Culture Around West Bengal. International Journal of Novel Research in Humanity and Social Science, 2(3), 1-5.

Kawuryan, S. P., Hastuti, W. S., \& Supartinah. (2018, Februari). Pengaruh Model pembelajaran tematik berbasis permainan tradisional dan scientific approach terhadap kemampuan berpikir kreatif. Cakrawala Pendidikan, hal. $71-84$.

Moma, L. (2015). Pengembangan instrumen kemampuan berpikir kreatif matematis untuk siswa SMP. Jurnal Matematika, 4(1), 27-41.

Purwaningsih, E. (2006). Permainan tradisional anak. Jurnal sejarah dan budaya, 1(1), 40-46.

Rahmawati, E. (2010). Bermain Asyik Permainan Tradisional . Jakarta : Multi Kreasi Satudelapan.

Rusman. (2015). Pembelajaran tematik terpadu. Jakarta: PT Raja Grafindo Persada.

Subali, B. \&. (2013). Pengembangan Kreativitas Keterampilan Proses Sains dalam Aspek Kehidupan Organisme pada Mata Pelajaran IPA SD. Cakrawala Pendidikan, 32(3), 365-381.

Sugiyono. (2015). Metode Penelitian Pendidikan. Bandung: Alfabeta.

Sugiyono. (2017). Statistika untuk Penelitian. Bandung: Alfabeta.

Trnova, E., \& TRNA, J. (2014). Implementation of Creativity in Science Teacher Training. International Journal on New Trends in Education and Their Implications, 5(3), 54-63.

Widodo, P., \& Lamintuarso, R. (2017). Pengembangan model Permainan Tradisional untuk Membangun Karakter pada Siswa SD Kelas Atas. Jurnal Keolahragaan, 5, 183-193. 